\title{
CORRECTION
}

Open Access

\section{Correction to: Quantum dots as targeted doxorubicin drug delivery nanosystems in human lung cancer cells}

\author{
Monika Ruzycka-Ayoush ${ }^{1 *} \mathbb{0}$, Patrycja Kowalik2,3, Agata Kowalczyk2, Piotr Bujak3 ${ }^{3}$ Anna M. Nowicka², \\ Maria Wojewodzka ${ }^{4}$, Marcin Kruszewski ${ }^{4,5}$ and Ireneusz P. Grudzinski ${ }^{1}$
}

The original article can be found online at https://doi. org/10.1186/s12645-02100077-9.

\section{${ }^{*}$ Correspondence:} mruzycka@wum.edu.pl

'Faculty of Pharmacy, Medical University of Warsaw, Banacha 1, 02-097 Warsaw, Poland

Full list of author information is available at the end of the article

\section{Correction to: Cancer Nanotechnol (2021) 12:8 https://doi.org/10.1186/s12645-021-00077-9}

Following publication of the original article (Ruzycka-Ayoush et al. 2021), the authors identified an error in article title.

The correct article title is "Quantum dots as targeted doxorubicin drug delivery nanosystems in human lung cancer cells".

The article title has been updated above and the original article (Ruzycka-Ayoush et al. 2021) has been corrected.

\section{Author details}

${ }^{1}$ Faculty of Pharmacy, Medical University of Warsaw, Banacha 1, 02-097 Warsaw, Poland. ${ }^{2}$ Faculty of Chemistry, University of Warsaw, Pasteura 1, 02-093 Warsaw, Poland. ${ }^{3}$ Faculty of Chemistry, Warsaw University of Technology, Noakowskiego 3, 00-664 Warsaw, Poland. ${ }^{4}$ Centre for Radiobiology and Biological Dosimetry, Institute of Nuclear Chemistry and Technology, Dorodna 16, 03-195 Warsaw, Poland. ${ }^{5}$ Department of Medical Biology and Translational Research, Institute of Rural Health, Jaczewskiego 2, 20-090 Lublin, Poland.

Published online: 11 March 2021

\section{Reference}

Ruzycka-Ayoush M, Kowalik P, Kowalczyk A, Bujak P, Nowicka AM, Wojewodzka M, Kruszewski M, Grudzinski IP. Quantum dots as targeted doxorubicin drug delivery nanosystems. Cancer Nanotechnol. 2021;12:8. https://doi.org/10.1186/ s12645-021-00077-9.

\section{Publisher's Note}

Springer Nature remains neutral with regard to jurisdictional claims in published maps and institutional affiliations. source, provide a link to the Creative Commons licence, and indicate if changes were made. The images or other third party material in this article are included in the article's Creative Commons licence, unless indicated otherwise in a credit line to the material. If material is not included in the article's Creative Commons licence and your intended use is not permitted by statutory regulation or exceeds the permitted use, you will need to obtain permission directly from the copyright holder. To view a copy of this licence, visit http://creativecommons.org/ licenses/by/4.0/. The Creative Commons Public Domain Dedication waiver (http://creativecommons.org/publicdomain/zero/1.0/) applies to the data made available in this article, unless otherwise stated in a credit line to the data. 